\title{
COMPACTIBILITY OF NEWLY FALLEN SNOW IN EASTERN CANADA*
}

\author{
By G. P. Williams \\ (Snow and Ice Section, Division of Building Research, National Research Council, \\ Canada)
}

\begin{abstract}
The critical density of newly fallen snow was measured during the 1956-57 winter season at two stations: Montreal Road Laboratories of the National Research Council, Ottawa, and the University of New Brunswick, Fredericton, New Brunswick. The relative compacted density or compactibility of newly fallen snow was found to depend on undisturbed density and snow temperature. A statistical equation was developed relating snow temperature and undisturbed density to the compacted density of the snow sample. Additional tests under cold room conditions indicate that grain size and grain-size distribution also have an appreciable effect on compacted density.

RÉsumé. Pendant la saison d'hiver 1956-1957 on a mesuré, près de deux stations, la densité critique de la neige fraîchement tombée. L'une de ces stations se trouvait dans les laboratoires du Conseil National des Recherches, route de Montréal à Ottawa, tandis que l'autre était située a l'Université du NouveauBrunswick, à Fredericton, dans la province du Nouveau-Brunswick. On s'est aperçu que la densité relative de compaction ou "compactibilité" de la neige fraîchement tombée dépendait de la densité naturelle de cette neige et de sa température. On a mis au point une équation statistique établissant un rapport entre la température d'une parcelle de neige et sa densité naturelle d'une part et sa densité de compaction d'autre part. D'autres essais effectués en chambre froide, ont permis de déceler l'effet sensible qu'ont la dimension des grains et leur répartition sur la densité de compaction.
\end{abstract}

INFORMATION on snow compaction is essential in solving many practical problems related to snow such as the development of over-snow vehicles, snow clearing by mechanical means and compacting snow for road construction. Although there have been some fundamental studies on snow compaction, ${ }^{\mathrm{I}}$ apparently no effort has been made to develop a means of measuring the variation in the compactibility of new snow under different climatic conditions. This report presents a simple method for measuring the compactibility of newly fallen snow. These compactibility measurements were taken for the Division of Building Research during the $1956-57$ season. While the emphasis in this report is on newly fallen snow the principles could probably be applied to other snow types.

Different procedures have been used for describing snow cover in terms of grain size, shape, density, and hardness. ${ }^{2,3}$ These measurements, however, do not always describe snow adequately from an engineering viewpoint. It is considered that a snow classification which treats the snow mass as an aggregate is more useful for engineering purposes than one based on individual constituents of the snow mass. This implies that the behaviour of a snow type can be predicted more readily from observations of how the snow mass behaves under various tests than by observations of grain size, shape, and distribution. Measurements on undisturbed density and hardness are measurements which treat the snow mass as an aggregate but few attempts have been made to relate these to the qualitative behaviour of snow. 4

In the field of soil mechanics attempts to relate grain-size characteristics to soil constants such as permeability have been consistently disappointing. 5 The trend has been to study the maximum and minimum porosities of granular soil in order to bring the complex phenomena of soil behaviour to a common basis. ${ }^{6,7}$

In studies by Nuttal and Finelli, ${ }^{8}$ the term "critical density" has been applied to snow types. In this paper the authors suggest that below this critical density snow will absorb normal stresses primarily through packing; above this critical density the snow cover will fail hydrodynamically. The work of Kragelski, ${ }^{9}$ indicates that there is a critical density for snow types, beyond which a great deal of additional energy is required to obtain a small increase in density.

* This is a contribution from the Division of Building Research of the National Research Council of Canada and is published with the approval of the Director of the Division. 
Fig. I compares the densities Kragelski obtained for the number of passes of a float, to the densities the author obtained by dropping a $1000 \mathrm{gm}$. weight through a height of $\mathrm{Io} \mathrm{cm}$. on confined snow samples. Both sets of data indicate that the critical density is dependent on snow temperature and is a measurable snow property. It was thus decided to measure the critical density along with other snow characteristics of newly fallen snow under a range of snow conditions.

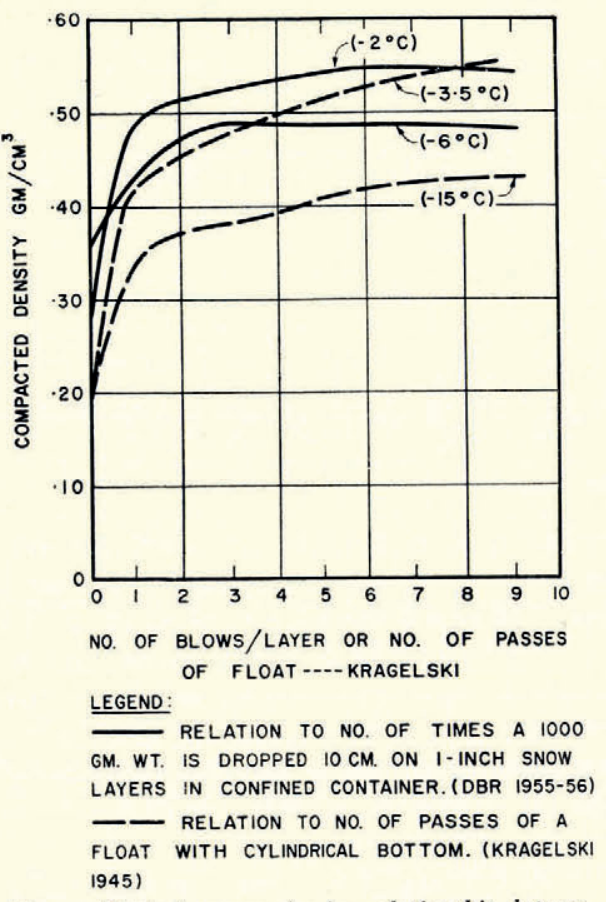

Fig. I. Typical curves showing relationship between compacted snow density and different methods of compacting
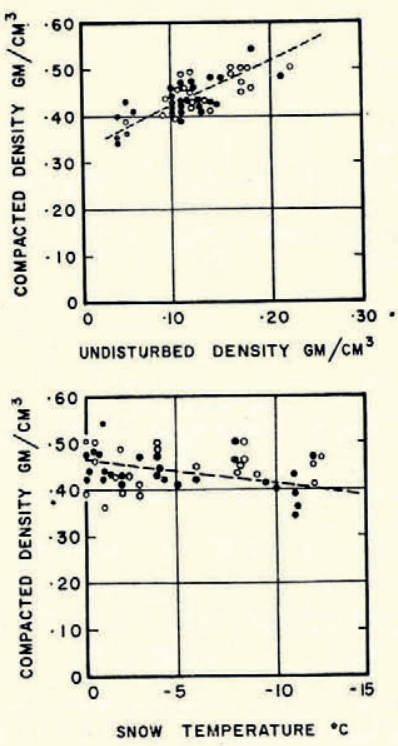

LEGEND:

- OTTAWA

- university of NEW BRUNSWICK

Fig. 2. Relationship between compacted density and undisturbed density and snow temperature

\section{Experimental Procedure}

The physical properties of newly fallen snow were investigated during the $1956-57$ winter season at two snow survey stations: the Montreal Road Laboratories of the National Research Council, Ottawa, and the University of New Brunswick at Fredericton, N.B. The following snow properties were recorded: snow temperature, undisturbed density, compacted density and snow hardness. In addition, the amount of each snowfall, general type of snow and air temperature were recorded.

Snow temperature, snow hardness and undisturbed density were measured using the same general procedure used in the Snow Survey of Canada. ${ }^{10}$ The compacted density was determined by dropping a $1000 \mathrm{gm}$. weight from a height of $10 \mathrm{~cm}$. on snow packed in layers in a $250 \mathrm{~cm} .^{3}$ container. This technique was developed for measuring the free water content of wet snow. ${ }^{\text {II }}$

In addition to measuring the properties of newly fallen snow, some compaction tests were made on granular snow in the cold room of the Division, in order to determine the effect of grain size and grain-size distribution on the density to which snow can be compacted.

\section{Experimental Results}

Fig. 2 shows the relationship between compacted density and undisturbed density; and 
between compacted density and snow temperature. These scatter diagrams indicate a general straight-line relationship between these variables.

Using the methods of correlation analysis outlined by Ezekiel, ${ }^{12}$ a statistical analysis was made of the data shown in Fig. 2.

The equation:

was obtained using:

$$
\Upsilon=0 \cdot 347+0 \cdot 750 X_{1}+0 \cdot 0005 X_{2}
$$

$$
\begin{gathered}
r=\text { compacted density in } \mathrm{gm} . / \mathrm{cm} .{ }^{3} \\
X_{1}=\text { undisturbed density in } \mathrm{gm} . / \mathrm{cm} .^{3} \\
X_{2}=\text { snow temperature }\left({ }^{\circ} \mathrm{C} .\right)
\end{gathered}
$$

The standard error of estimate for this equation was found to be equal to $0.025 \mathrm{gm} . / \mathrm{cm} .3$ which measures the closeness with which the estimated values agree with the original values. In other words, by knowing the undisturbed density and snow temperature, it is possible to estimate the compacted density within $\pm 0.025 \mathrm{gm} . / \mathrm{cm} .{ }^{3}$ approximately 70 per cent of the time.

The coefficient of multiple correlation was calculated to be equal to $0 \cdot 77$. This figure gives a measure of the proportion of the variation in the compacted density which can be explained by variation in snow temperature and undisturbed density values. While this coefficient is not high it must be remembered that these data were obtained under field conditions by independent observers, and therefore some of the variation is probably due to experimental techniques.

The main value of equation ( $\mathrm{I}$ ) is that the relative compacted density or compactibility of newly fallen snow can be estimated and compared by making two simple snow measurements: undisturbed density and snow temperature.

Two variables which were not measured but which might affect the compacted density are grain size and grain-size distribution. In newly fallen snow it is difficult to make any objective measurement of these two variables. It is possible that undisturbed density does give a measure of their effect. To evaluate the effect of grain size and grain-size distribution, compaction tests were conducted in the laboratory on granular snow, screened to different grain sizes and grain-size distribution.

Table I records the results of these compaction tests under constant cold room tempera-

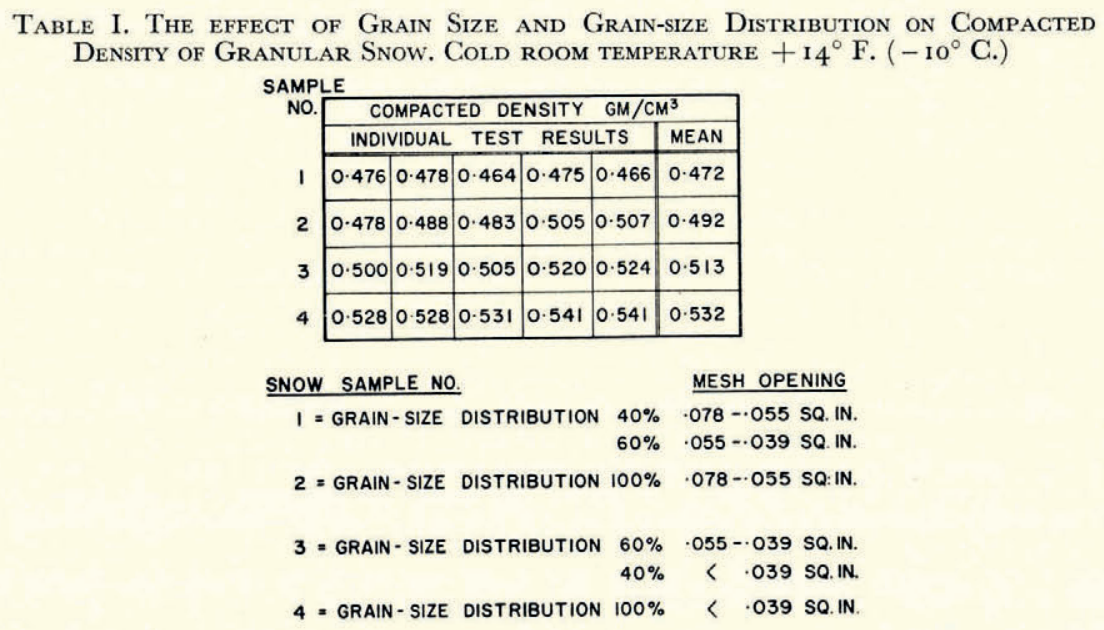

ture of $+14^{\circ}$ F. $\left(-10^{\circ}\right.$ C. $)$. Sample No. 2 compared with No. 4 indicates that the finer grain size can be compacted to a higher density than the coarse grain size. Sample No. I compared 
with sample No. 3 indicates that the proportion of fines in the material also can affect the compacted density. A comparison of sample No. I and sample No. 2 indicates that this is not necessarily true. Probably some measure of grain shape is also needed to analyse these tests properly. In general this result is similar to porosity determinations of granular materials, which indicate that the higher the proportion of smaller particles the denser the packing of the material. ${ }^{13}$ It should be emphasized that this laboratory experiment was with old granular snow and the results do not necessarily apply to freshly fallen snow.

\section{Conclusions}

The measurements made on the properties of newly fallen snow indicate that the density to which freshly fallen snow can be compacted by a standard technique is largely dependent on the snow temperature and the undisturbed density. These tests were made on dry snow.

It has been shown ${ }^{I I}$ that the compacted density of wet snow depends on the amount of free water held in the wet snow. Further tests might indicate that a modified form of equation (I) would be valid for wet snow conditions.

The measurements required are simple and can readily be done under field conditions. The data obtained indicate that reasonably consistent results can be obtained by observers located several hundred miles apart.

It has also been shown that the smaller the proportion of fine, granular snow, the higher the compacted density. It is possible that the undisturbed density term in equation (I) gives some measure of the grain size and grain-size distribution effect.

\section{Acknowledgements}

The author is indebted to the observers Messrs. J. McNally and D. L. Seheult for taking the field observations at Ottawa and Fredericton respectively, and to Mr. L. W. Gold for helpful criticism of this report.

Special acknowledgement is also made of the co-operation of Professor L. R. Seheult, Faculty of Forestry, University of New Brunswick, under whose supervision the work at Fredericton was carried out.

MS. received II December 1957

\section{REFERENGES}

I. Taylor, A. Snow compaction. Snow, Ice and Permafrost Research Establishment, Report No. I3, 1953.

2. The International Classification of Snow (with special reference to snow on the ground) issued by the Commission on Snow and Ice of the International Association of Hydrology. National Research Council of Canada, Associate Committee on Soil and Snow Mechanics, Ottawa, Technical Memorandum 31, 1954.

3. Smith-Johannsen, R. Snow data. Union Géodésique et Géophysique Internationale. Association Internationale d'Hydrologie Scientifique. Assemblée Générale d'Oslo, Tome 2, 1948, p. I53-56.

4. Gold, L. W. The strength of snow in compression. Journal of Glaciology, Vol. 2, No. 20, 1956, p. 719-25.

5. Terzaghi, K., and Peck, L. Soil mechanics in engineering practice. John Wiley \& Sons, 1948.

6. Burmister, D. M. The importance and practical use of relative density in soil mechanics. Proceedings, American Society for Testing Materials, Vol. 48, 1948, p. 1249-68.

7. Kolbuszewski, J. J. An experimental study of the maximum and minimum porosities of sand. Proceedings, Second Int. Conference on Soil Mechanics and Foundation Engineering, 1948, p. 158-65.

8. Nuttal, C. J., and Finelli, J. P. Vehicles in snow. A critical review of the state of the art. U.S. Army, Corps of Engineers, Waterways Experiment Station, Vicksburg, Miss. Tech. Memo. No. 3-414, 1955.

9. Kragel'skiy, I. V. Tekhnologicheskiy analiz orudiy dlya uplotneniya snega [Technological analysis of snow compression equipment]. (In Fizikomekhanicheskiye svoystva snega $i$ ikh primeneniye $v$ aerodromnom $i$ dorozhom stroitel'stve [Physical and mechanical properties of snow and their utilization in airfield and road construction]. Moscow, Akademiya Nauk SSSR [Academy of Sciences of the U.S.S.R.], 1945, p. 29-42.)

Io. Klein, G. J., Pearce, D. C., and Gold, L. W. Method of measuring the significant characteristics of a snow cover. National Research Council of Canada, Associate Committee on Soil and Snow Mechanics, Ottawa, Technical Memorandum $18,1950$.

I I. Williams, G. P. A field determination of the free water content in wet snow. Proceedings, Western Snow Conference 1956. (Also issued by National Research Council of Canada, Division of Building Research, as NRC No. 4110.$)$

12. Ezekiel, M. Methods of correlation analysis. Second Edition, John Wiley \& Sons, r953.

13. Muskat, M. The flow of homogeneous fluids through porous media. Ann Arbor, J. W. Edwards, 1946. 